\title{
Analyses of Post Harvest Management Practices of Sericulture Entrepreneur in Raichur, India
}

\author{
G.N. Maraddi ${ }^{1 *}$, I. Moulasab ${ }^{2}$ and Nagesh $^{3}$ \\ ${ }^{1}$ Agricultural Extension Education Centre, University of Agricultural Sciences, \\ Raichur, Karnataka, India \\ ${ }^{2}$ Directorate of Extension, University of Agricultural Sciences, Raichur, Karnataka, India \\ ${ }^{3}$ ARS, Guladalli, University of Agricultural Sciences, Raichur, Karnataka, India \\ *Corresponding author
}

\begin{tabular}{|c|c|}
\hline & A B S T R A C T \\
\hline & \multirow{6}{*}{$\begin{array}{l}\text { The research study on "Analyses of post harvest management practices of sericulture } \\
\text { entrepreneur was conducted in Zone III of north eastern part of Karnataka. The ex-post } \\
\text { facto research design along with snowball method of sampling is used for the study. It was } \\
\text { corroborated that, } 92 \text { per cent of respondents fallowing } 4 \text { day harvest and } 5 \text { day sale during } \\
\text { summer followed by } 5 \text { day harvest and } 6 \text { day sale during winter. Around sixty per cen } \\
\text { respondents were taken by initial cleaning and seventy per cent of them involving in } \\
\text { separation of inferior cocoons from lot. Seventy per cent of respondents used eye sigh } \\
\text { grading with free from urination fallowed by cocoon shape ( } 30.00 \%) \text {, uniform size } \\
(26.66 \%) \text {. Cent per cent of the entrepreneurs were using plastic netrike. It was reviewed } \\
\text { that, Correlation analyses observed that, management variation and information } \\
\text { management of the respondents has shown positive and significant relationship with the } \\
\text { adoption of PHM practices at } 1 \text { per cent probability and Whereas education, land holding } \\
\text { risk orientation, innovative proneness of respondents shown } 5 \text { probability. Cent per cent o } \\
\text { the respondents expressed the major problem of non availability of regulated markets in } \\
\text { their locality followed by lack of labour availability and inadequate govt. incentives for } \\
\text { construction of rearing shed ( } 96.66) \text {, higher initial cost of rearing unit (91.66), higher trenc } \\
\text { of price fluctuation in the market (90.00), non availability of required electricity facility } \\
\text { ( } 76.66 \text { ) and only } 23 \text { per cent of the respondents perceived the constraints of non } \\
\text { availability of tree species in mulberry crop. }\end{array}$} \\
\hline & \\
\hline $\begin{array}{l}\text { PHM practices, } \\
\text { Sericulture } \\
\text { enterprise, } \\
\text { Correlation analyses }\end{array}$ & \\
\hline Article Info & \\
\hline $\begin{array}{l}\text { Accepted: } \\
\text { 12 March } 2019 \\
\text { Available Online: } \\
10 \text { April } 2019\end{array}$ & \\
\hline & \\
\hline
\end{tabular}

\section{Introduction}

Indian sericulture farms manufacture four types of silk - Mulberry, Tassar, Eri and Muga of which Mulberry silk accounts for 90 per cent of the total silk production in the country. In rain fed areas, mulberry is planted at a distance of $7.6 \times 7.6 \mathrm{~cm}$ in rows at locations where the temperature ranges from 160 to 310 degrees Celsius. The silkworm Bombyx Mori is reared throughout the year. The total life span of this silkworm is 50 days. At the end of the larval duration, the silkworm emits silk from its mouth and builds a cocoon on scaffolding. The average annual yield of cocoons in India is as low as $150 \mathrm{kgs}$ under 
rain fed conditions and $400 \mathrm{kgs}$ under irrigated conditions. The silk is removed from the cocoons by cooking the cocoons in hot water. There are over 60 lakh (External website that opens in a new window) persons are engaged in various sericulture activities in the country. Karnataka is one of the leading States where sericulture is practiced. The districts of Dharwad and Tumkur are the most popular silk producing regions as they have the perfect sub humid to dry semi arid climate. Here sericulture involves two steps. The first one is the cultivation of mulberry gardens, as mulberry leaves are the only form of food for silkworms. The second is the construction of a shed to ensure specific climatic conditions of humidity between 70 to 80 per cent and a temperature of 27 degrees Celsius. The process from egg to cocoon takes around a month. Nursery raising, rainwater harvesting, incubation, black boxing, biomass trench system and vermin composting play a big part in the rearing of silk worms in Karnataka.

Karnataka is home to the Central Sericultural Research and Training Institute (External website that opens in a new window), which is located in the city of Mysore. This body is the pioneer research institute in the field of sericulture. It is responsible for developing new technologies, conducting research, training personnel and testing silk machinery. The Central Silk Board (External website that opens in a new window) is also located in the State of Karnataka. Assam (File referring to external site opens in a new window) is another major producer of silk in India. Sualkuchi is the biggest centre of silk production and weaving in the State. The main varieties of silk produced are Muga and Eri silk. Mulberry and Oak Tassar are also made in limited quantities. Other major silk producing states in the country are Andhra Pradesh and Tamil Nadu. Sericulture is an ideal crop to improve North Karnataka which has congenial soil, climate, man power and the opportunity for development of socioeconomic conditions. In this region, through cluster model, sericulture development work will be taken up. To improve the quality of raw silk, bivoltine hybrid cocoon production will be enhanced. In addition post harvest management practices are playing pivotal role in reducing the wastage and deriving better price for the cocoons in the market. With this background the research study is being conducted to analyze the Post harvest management practices in sericulture enterprises

\section{Materials and Methods}

The research study was conducted in Zone III of north eastern part of Karnataka to analyze the postharvest management practices of sericulture entrepreneur. The Raichur district was purposively selected with criterion of highest number of sericulture entrepreneur existed in the district. The ex-post-facto research design was used for the study. Since Sericulture farmers are scattered over the sample area, hence, Snowball method of sampling is being used in order to avail required sample size for conduct of research. The structured and standard schedule used for the study. The suitable statistical tools were used to explore qualitative inferences from the analyses. In addition standard procedure used to measure independent variables of the respondents.

\section{Results and Discussion}

\section{Existing PHM Practices Followed by Sericulture Entrepreneur}

It was observed from the table 1 that, about 92 percent of respondents fallowing 4 day harvest and 5 day sale during summer followed by 5 day harvest and 6 day sale during winter. Whereas harvesting of cocoons 
carried out based pupation particularly on 3 day harvest and 4 day sale. The initial cleaning at shed is being taken by around sixty percent $(63.33 \%)$, whereas seventy percent of them involving in separation of inferior cocoons from lot. In case of eye sight grading, seventy percent of respondents grade the produce with free from urination fallowed by cocoon shape $(30.00 \%)$, uniform size $(26.66 \%)$ and free from snappy/gridness. Cent percent of the entrepreneurs were using plastic netrike in spite of advantages like better aeration and absorption of liquid extract is being noticed in bamboo chandrike. The probable reason might be escalation in cost of bamboo chandrike/wood in recent past in addition to non availability bamboo. With regard to mode of transport, around 70 percent of respondents taking their produce to Ramnagar market through bus fallowed by Train $(30 \%)$. All the respondents were availed Government of Karnataka incentives for their improvement of their respective enterprise.

\section{Comparative analyses of existing PHM Practices with the recommended technologies}

It was corroborated that higher trend is being noticed in harvesting during winter (5 day harvest and 6 day sale) and Summer (4 day harvest and 5 day sale) and more than fifty percent of respondents practicing pupation parameter for harvesting as existing PHM practices. Around thirty percent harvesting gap trend is observed in winter and based on pupation indicator and negligible gap trend observed in summer. Around seventy percent of respondents undertaking initial cleaning of cocoons at shed followed by separation of inferior cocoons from lot (63\%) and negligible gap trend is being noticed in both cleaning at shed as well as from lot also. With regard to eye sight grading, seventy percent of respondents are undertaken grading method of separation of good cocoons from urination followed by cocoon shape, uniform size and free from snappy as well. The significant gap trend $(75 \%)$ is being noticed in grading activities like free from snoopy followed by uniform size, cocoon shape and free from urination (Table 2).

\section{Profile of sericulture entrepreneur}

The data in table 3 revealed that 60.83 per cent of respondents were middle aged. Middle aged farmers are more enthusiastic have more knowledge and experience regarding sunflower cultivation. Respondents between 30 to 49 years age group generally have more physical vigour, active in adoption of agricultural practices and also have more responsibility towards family than younger ones. Thus, most of the sunflower growers were from middle age group that could be justified. The above findings got support from the studies conducted by studies of Nagesh (2006), and Raghavendra (2007). Less than half $(37.50 \%)$ of the per cent illiterate. 17.50 per cent of respondents were educated up to primary school followed by middle school (14.17\%), high school (15.83\%), preuniversity $(9.17 \%)$ and only 5.83 per cent of them were educated up to degree and above. The results could be attributed to the availability of no free basic education and the educational infrastructure in the study area. Few of them opted higher education reflecting on their affordability and interest to learn more and gain good knowledge. The data in table 3 indicated that, 36.67 and 34.17 per cent of the respondents had the farming experience of 8 to 16 years and more than 17 years, respectively. As the study area is potential area of sunflower and cotton cultivation and most of the farmers were getting benefits from these crops. Since other farmers also might be convinced by the progressive farmers about the advantages of cultivating the crops and this might be reason those farmers bearing more experience in 
cultivation of crops. The results are in line with the findings of Natikar (2001) and Binkadakatti (2008). 30.83 per cent of respondents belonged to small land holders category followed by big (29.17\%), medium $(27.50 \%)$ and 12.50 per cent of them belonged to marginal land holding category. Size of land holding depends on their ancestral background, which is being transferred from one generation to another. The study area greatly has the plain land and in such lands small holdings are common unlike in hilly and coastal zones. Sunil Kumar (2004) and Shashidhara (2004) reported similar findings.

With respect to extension contact table 3 the results revealed that, majority of the respondents $(54.17 \%)$ belonged to low extension contact category and only 27.50 per cent of respondents were noticed in high extension contact categories. The possibility of getting information from informal sources, non-availability of extension workers at time of farmers call might be the possible reasons for the situation. In view of this concerned extension agencies should take utmost measures to strengthen extension workers and their capacity building for solving the problems of farmers. The above findings were in accordance with the findings of study conducted Aghazia (2008). The economic position of the farmers in the table 3 revealed that, 40.00 per cent of the respondents belonged to low annual income level followed by semi medium $(30.00 \%)$ ), high $(21.67 \%)$ and 8.33 per cent of them belonged to medium annual income category. The possible reason might be the low land holdings coupled with taking one crops in a year. Both kharif and summer crops are taken up by the farmers and majority farmers of the area are highly skilful and are not engaged in seed production of sunflower. All these factors could have favourably influenced the respondents to obtain low to medium income. Majority $(40.83 \%)$ of the respondents belonged to low followed by high $(30.83 \%)$ and medium $(28.33 \%)$ material possession. This might be due to the nearly three fourth of the respondents belonged to low income category. Also to have status in society, now a day the materials such as television, mobile, motor cycle have become essential than luxury.

With regard to risk orientation table 3 , more than fifty per cent $(82.50 \%)$ of the respondents had medium risk orientation, followed by 12.50 and 5.00 per cent of respondents belonged to low and high risk orientation categories, respectively (table 3 ). It should be mentioned here, that the individuals will be very critical and cautious in understanding different aspects of technology. There is tendency in farmers to take risk based on their income level, land holding and other resources. Risk taking varies with personal and socio economic status of the individuals and also one fifth of the respondents were illiterate. These could have contributed for the present finding. Similar result was reported by Vijay Kumar (2001) and Chandramouli (2005). In case of cropping intensity table 3 , majority $(52.50 \%)$ of the respondents belonged to high cropping intensity category followed by low $(29.17 \%)$ and medium $(18.33 \%)$ cropping intensity categories, respectively. The incidence of high cropping intensity might be due to more dependence on canal water by the majority of the respondents. The result shown in the table 3 revealed that, 51.67 per cent of the sunflower growers had medium scientific orientation whereas, 26.67 and 21.67 per cent of them had high and low level of scientific orientation respectively. Scientific orientation is the orientation of farmer to adopt new technologies in a scientific way (Table 4). 
Table.1 Existing post-harvest management practices followed by sericulture Entreprene $n=60$

\begin{tabular}{|c|c|c|c|}
\hline \multirow{2}{*}{$\begin{array}{l}\text { Sl. No. } \\
1\end{array}$} & \multicolumn{3}{|l|}{ Post-Harvest Management Practices } \\
\hline & Harvesting & Frequency & $(\%)$ \\
\hline & a. Winter -5 day Harvest and 6 day sale & 42 & 70.00 \\
\hline & b. Summer - 4 day Harvest and 5 day sale & 55 & 91.66 \\
\hline & c. Based on pupation -3 day harvest and 4 day sale & 34 & 56.66 \\
\hline 2 & Initial Cleaning of cocoons at shed & 38 & 63.33 \\
\hline 3 & Separation of inferior cocoons from lot & 42 & 70.00 \\
\hline \multirow[t]{5}{*}{4} & Eye sight grading & & \\
\hline & a. Uniform size & 16 & 26.66 \\
\hline & b. Free from urination & 42 & 70.00 \\
\hline & c. Cocoon shape & 18 & 30.00 \\
\hline & d. Free from snappy / Gridness / firmness' & 15 & 25.00 \\
\hline \multirow[t]{3}{*}{5} & Quality cocoons can get & frequency & $\%$ \\
\hline & $\begin{array}{l}\text { a. Bamboo chadrika - Good quality cocoon } \\
\text { (Better aerations and absorption of liquid extract) }\end{array}$ & 00 & 00 \\
\hline & $\begin{array}{l}\text { a. Plastic netrike -Inferior cocoons } \\
\text { (No better aerations and absorption of liquid extract) }\end{array}$ & 60 & 100 \\
\hline \multirow[t]{3}{*}{6} & Mode of transport followed & & \\
\hline & a. Bus/Private vehicle & 41 & 68.33 \\
\hline & b. Train & 19 & 31.66 \\
\hline \multirow[t]{4}{*}{7} & Marketing pattern used & & \\
\hline & a. Where - Ram Nagar & 60 & 100 \\
\hline & b. When - Immediately harvest & 60 & 100 \\
\hline & c. Which Method - Open Auction Method & 60 & 100 \\
\hline \multirow[t]{3}{*}{8} & Benefits availed from government scheme: & & \\
\hline & a. 10/- per $\mathrm{kg}$ as Transportation cost & 60 & 100 \\
\hline & b. 40/-per kg as incentives (GOK) & 60 & 100 \\
\hline
\end{tabular}

Table.2 To compare the existing PHM practices with the recommended technologies $n=60$

\begin{tabular}{|l|l|c|c|c|c|}
\hline SI. & Post-Harvest Management Practices & \multicolumn{2}{l|}{$\begin{array}{l}\text { Existing Trend } \\
(\mathbf{\%})\end{array}$} & \multicolumn{2}{l|}{$\begin{array}{l}\text { Gap Trend with } \\
\text { Recommended } \\
(\mathbf{\%})\end{array}$} \\
\hline $\mathbf{1}$ & $\begin{array}{l}\text { Harvesting } \\
\text { a. Winter -5 day Harvest and 6 day sale } \\
\text { b. Summer - 4 day Harvest and 5 day sale }\end{array}$ & 42 & 70.00 & 18 & 30.00 \\
& $\begin{array}{l}\text { c. Based on pupation -3 day harvest and 4 day sale } \\
\mathbf{2}\end{array}$ & 34 & 51.66 & 05 & 8.33 \\
\hline $\mathbf{3}$ & Initial Cleaning of cocoons at shed & 42 & 70.00 & 18 & 30.00 \\
\hline $\mathbf{4}$ & Separation of inferior cocoons from lot & 34 & 63.33 & 26 & 43.33 \\
\hline & $\begin{array}{l}\text { Eye sight grading } \\
\text { a. Uniform size, }\end{array}$ & 16 & 26.66 & 44 & 73.33 \\
& $\begin{array}{l}\text { b. Free from urination } \\
\text { c. Cocoon shape }\end{array}$ & 42 & 70.00 & 18 & 3070 \\
& d. Free from snappy / Gridness / firmness' & 18 & 30.00 & 42 & 70.00 \\
\hline
\end{tabular}


Table.3 Distribution of respondents according to their personal and socio-economic characteristics $n=60$

\begin{tabular}{|c|c|c|c|}
\hline SI. No. & Category & Frequency & Percentage \\
\hline \multirow[t]{4}{*}{1} & \multicolumn{3}{|l|}{ Age } \\
\hline & Young (Less than 30) & 08 & 13.33 \\
\hline & Middle (Between 30-49) & 37 & 61.67 \\
\hline & Old (More than 50) & 15 & 25.00 \\
\hline \multirow[t]{7}{*}{2} & \multicolumn{3}{|l|}{ Education level } \\
\hline & Illiterate & 23 & 38.33 \\
\hline & Primary & 10 & 16.67 \\
\hline & Middle school & 08 & 13.33 \\
\hline & High school & 09 & 15.00 \\
\hline & Pre-university & 06 & 10.00 \\
\hline & Degree and above & 04 & 06.67 \\
\hline \multirow[t]{5}{*}{3} & \multicolumn{3}{|l|}{ Farming Experience } \\
\hline & Low (up to 8 years) & 22 & 36.67 \\
\hline & Medium (9-16 years) & 18 & 30.00 \\
\hline & High (17 and above) & 20 & 33.33 \\
\hline & \multicolumn{3}{|l|}{ Mean $=22.77 \quad S D=13.74$} \\
\hline \multirow[t]{5}{*}{4} & \multicolumn{3}{|l|}{ Land holding } \\
\hline & Marginal farmers (up to 1 ha) & 08 & 13.33 \\
\hline & Small farmers (1 to 2 ha) & 18 & 30.00 \\
\hline & Medium farmers ( 2 to 4 ha) & 16 & 26.67 \\
\hline & Big farmers $(>4$ ha $)$ & 18 & 30.00 \\
\hline \multirow[t]{5}{*}{5} & \multicolumn{3}{|l|}{ Annual income } \\
\hline & Low (Up to Rs 17,000$)$ & 24 & 40.00 \\
\hline & Semi medium (Rs 17,001-Rs 34,000) & 18 & 30.00 \\
\hline & Medium (Rs 34,001- Rs 51,000) & 05 & 08.33 \\
\hline & High (Above Rs 51,001) & 13 & 21.67 \\
\hline \multirow[t]{5}{*}{6} & \multicolumn{3}{|l|}{ Material possession } \\
\hline & Low (Mean - $0.425 * \mathrm{SD})$ & 24 & 40.00 \\
\hline & Medium $($ Mean $\pm 0.425 *$ SD $)$ & 17 & 28.33 \\
\hline & High $($ Mean $+0.425 * S D)$ & 19 & 31.67 \\
\hline & Mean $=4.56 \quad \mathrm{SD}=4.05$ & & \\
\hline \multirow[t]{5}{*}{7} & \multicolumn{3}{|l|}{ Risk orientation } \\
\hline & Low (Mean $-0.425^{*}$ SD) & 08 & 13.33 \\
\hline & Medium $($ Mean $\pm 0.425 *$ SD) & 49 & 81.67 \\
\hline & High $($ Mean $+0.425 * S D)$ & 03 & 05.00 \\
\hline & Mean $=4.32 \quad \mathrm{SD}=1.03$ & & \\
\hline \multirow[t]{5}{*}{7} & \multicolumn{3}{|l|}{ Cropping intensity } \\
\hline & Low (Mean $-0.425 * \mathrm{SD})$ & 17 & 28.33 \\
\hline & Medium $($ Mean $\pm 0.425 *$ SD) & 11 & 18.33 \\
\hline & High $($ Mean $+0.425 *$ SD $)$ & 32 & 53.33 \\
\hline & Mean $=81.44 \quad S D=25.85$ & & \\
\hline \multirow[t]{5}{*}{8} & \multicolumn{3}{|l|}{ Scientific orientation } \\
\hline & Low (Mean - $0.425 *$ SD) & 13 & 21.67 \\
\hline & Medium $($ Mean $\pm 0.425 * \mathrm{SD})$ & 31 & 51.67 \\
\hline & High $($ Mean $+0.425 * \mathrm{SD})$ & 16 & 26.67 \\
\hline & Mean $=9.47 \quad \mathrm{SD}=1.51$ & & \\
\hline \multirow[t]{5}{*}{9} & \multicolumn{3}{|l|}{ Management orientation } \\
\hline & Low (Mean $-0.425^{*}$ SD) & 15 & 25.00 \\
\hline & Medium $($ Mean $\pm 0.425 *$ SD $)$ & 21 & 35.00 \\
\hline & High $($ Mean $+0.425 * S D)$ & 24 & 40.00 \\
\hline & Mean $=72.06 \quad \mathrm{SD}=8.67$ & & \\
\hline
\end{tabular}


Table.4 Correlation between selected independent variables of sericulture entrepreneur with their practices

\begin{tabular}{|c|l|c|}
\hline SI. No. & \multicolumn{1}{|c|}{ Variables } & Correlation coefficient \\
\hline $\mathbf{1 .}$ & Age & $-0.314^{* *}$ \\
\hline $\mathbf{2 .}$ & Education & $0.318^{*}$ \\
\hline $\mathbf{3 .}$ & Land Holding & $0.209^{*}$ \\
\hline $\mathbf{4 .}$ & Farming experience & $-0.268^{*}$ \\
\hline $\mathbf{5 .}$ & Risk orientation & $0.239^{*}$ \\
\hline $\mathbf{6 .}$ & Management orientation & $0.492^{* *}$ \\
\hline $\mathbf{7 .}$ & Innovative proneness & $0.349^{*}$ \\
\hline $\mathbf{8 .}$ & Information management & $0.472^{* *}$ \\
\hline
\end{tabular}

$*$ Significant at $5 \%$

** Significant at $1 \%$

NS- Non Significant

Table.5 Constraints faced by sericulture entrepreneur $n=60$

\begin{tabular}{|c|l|c|c|}
\hline Sl. No. & \multicolumn{1}{|c|}{ Constraints } & Frequency & $\%$ \\
\hline $\mathbf{1 .}$ & Lack of labour availability and higher wages & 58 & 96.66 \\
\hline $\mathbf{2 .}$ & Non availability of required electric facility & 46 & 76.66 \\
\hline $\mathbf{3 .}$ & Non availability of tree species in mulberry crop & 14 & 23.33 \\
\hline $\mathbf{4 .}$ & Non availability of regulated markets in their locality & 60 & 100.00 \\
\hline $\mathbf{5 .}$ & Higher transaction cost & 36 & 60.00 \\
\hline $\mathbf{6 .}$ & Higher initial cost of Rearing unit & 55 & 91.66 \\
\hline $\mathbf{7 .}$ & Inadequate govt. incentives for construction of rearing shed & 58 & 96.66 \\
\hline $\mathbf{8}$ & Higher trend of price fluctuation in the market & 54 & 90.00 \\
\hline
\end{tabular}

Over one third $(39.17 \%)$ of the respondents belonged to high management category followed by exact one third $(35.00 \%)$ with medium and near one fourth $(25.83 \%)$ with low management orientation category. This warranted better management orientation on the part of sunflower growers in the utilization of water, land, improved cultivation practices and the overall efficiency of farm management.

\section{Zero order relationship between selected independent variables of sericulture entrepreneur with their PHM practices}

It was observed from the correlation relationship between variables, Management
Variation and information management of the respondents has shown positive and significant relationship with the adoption of post harvest management practices at 1 per cent level of probability. Whereas education, land holding, risk orientation, innovative proneness of respondents with their PHM practices at 5 per cent level of probability. In addition age of the respondents has shown negative and significant relationship with their PHM practices. It shows that as older the age of the respondents their adoption of PHM practices gradually decreasing trend, it seems younger age respondents are relatively better in adoption of PHM practices than old age respondents. 
Analyses of constraints faced by sericulture Entrepreneur in adoption of post harvest management practices

It was observed from the analyses (Table 5) cent percent of the respondents expressed the major problem of non availability of regulated markets in their locality followed by both lack of labour availability and inadequate govt. incentives for construction of rearing shed (96.66), higher initial cost of rearing unit (91.66), higher trend of price fluctuation in the market (90.00), non availability of required electricity facility (76.66) and only 23 percent of the respondents perceived the constraints of non availability of tree species in mulberry crop.

Based on the detailed analyses of the research study, more significantly constraints analyses, the suitable policy implications are explored from the research study.

\section{Policy implications}

Establishment of ARM (Automatic Reeling Machine) - Govt. Agencies.

Need of location specific tree mulberry species in Zone 2 and zone 3.

Subsidy amount should be increased for construction of rearing shed.

\section{References}

Binkadakatti, J. S., 2008, Impact of Krishi Vigyan Kendra (KVK) trainings on use of bio-fertilizers and bio-pesticides by Tur farmers in Gulbarga district. M.Sc.
(Agri.) Thesis, Univ. Agric. Sci., Dharwad (India).

Maraddi, G. N., 2006, An analysis of sustainable cultivation practices followed by Sugarcane growers in Karnataka. Ph. D. Thesis, Univ. Agric. Sci., Dharwad, Karnataka (India).

Nagesh, 2006, Study on entrepreneurial behavior of pomegranate growers in Bagalkot district of Karnataka, M. Sc. (Agri.) Thesis, Univ. Agric. Sci., Dharwad, (India).

Natikar, K. V., 2001, Attitude and use of farm journal by the subscriber farmers and their profile. A critical analysis. Ph. D. Thesis., Uni. Agric. Sci. Dharwad, Karnataka (India).

Raghavendra, N. B., 2007, A study on management practices of pineapple growers in Karnataka. M. Sc. (Agri.) Thesis, Univ. Agric. Sci., Dharwad, Karnataka.

Raghavendra, N., 2007, An economic analysis of red banana production under contract farming. M. Sc. (Agri.) Thesis, Univ. Agric. Sci., Dharwad, Karnataka (India).

Sunilkumar, G. M., 2004, A study on farmer's knowledge and adoption of production and post harvest technology in Tomato crop of Belgaum district in Karnataka. M. Sc. (Agri.) Thesis, Univ. Agric. Sci., Dharwad, Karnataka (India).

Shashidhar, D. N., 2004, A study on influencing factors and constraints in drip irrigation by horticulture farmers of Bijapur district of Karnataka. M. Sc. (Agri.) Thesis, Univ. Agric. Sci., Dharwad, Karnataka (India).

\section{How to cite this article:}

Maraddi, G.N., I. Moulasab and Nagesh. 2019. Analyses of Post Harvest Management Practices of Sericulture Entrepreneur in Raichur. Int.J.Curr.Microbiol.App.Sci. 8(04): 1498-1505. doi: https://doi.org/10.20546/ijcmas.2019.804.175 